\title{
Demand versus Capacity of Tsunami Shelters in Padang, Indonesia
}

\author{
Yosritzal $^{\#}$, Badrul Mustafa Kemal ${ }^{\#}$, Yoga Bimo Aulia ${ }^{\#}$

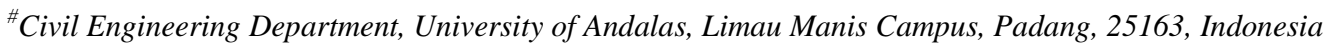 \\ E-mail: yosritzal@ft.unand.ac.id,badrulgeof76@yahoo.com,yogabimoaulia@gmail.com
}

\begin{abstract}
This paper presents an estimation of demand and its comparison to the capacity of the existing tsunami shelters in Padang. A combination of horizontal and vertical evacuation plans was simulated with giving priority to the horizontal ones. Demand for the existing shelters was estimated with an assumption that the population is spreading uniformly within the administrative area. It was also assumed that the number of people who entered the area is the same as those who went out of the area at the time of the anticipated earthquake occur. The coverage areas of shelters were estimated based on the distance that can be reached by people within an effective available evacuation time. The capacity of the tsunami shelters was obtained from secondary data. The study found that almost half of the existing shelters in Padang will be overloaded if all of the people in the coverage area of a shelter being evacuated to the shelters. Addition of 37 more shelters with a capacity of 2000 is needed.
\end{abstract}

Keywords — Padang; disaster; tsunami; shelter; demand; capacity.

\section{INTRODUCTION}

Learning from other countries in preparing for tsunami mitigation, Padang City has put tremendous efforts in developing tsunami early warning systems, increasing the capacity of tsunami evacuation route, building new shelters, evaluating and retrofitting structure of existing many-storey buildings and preparing the rooftop of the buildings as temporary evacuation sites or shelters [1]. As much as 24 buildings are declared as temporary evacuation sites or shelters of the tsunami in 2015 [2]. Many studies have been aimed to learn the use of the shelters such as [3] and [4]. However, the adequacy of the building has not been carefully calculated.

It is a well-known policy in Padang that during the tsunami evacuation, people are suggested to leave their cars and evacuate on foot immediately to the nearest shelters or the safety zones [5]. The use of car has been confirmed to make evacuation more difficult due to traffic jam and bottleneck [6]. A majority of car users preferred to park on street either legally or illegally in Padang, the evacuation routes become more vulnerable to a massive traffic jam during the rush hour and the evacuation.

However, in fact, panic during previous earthquakes in Padang causes congestion in all of the tsunami evacuation routes. Everybody did horizontal evacuation using their cars, but none of them could pass through the traffic and reach the safety zone within the available evacuation time (for example, see [7]. If only the tsunami happened at the time, the impact could not be imagined.
The government has been educating people using religious words, which was used in many countries during the earthquake in Japan to provoke emotions of the people to make it easier for them to understand the situation [8]. However, it seems that the government has hesitant in implementing the policy to save as many people as they could. This might be because they were not confident that the buildings were safe nor the capacity of the shelters was adequate. The adequacy of shelters is an important thing before the government implementing the evacuation plans. Major of Padang is calling experts from universities to help them in the mitigation; plans [9].

This paper aims to immediately answer the call by seeking the ratio of demand and capacity and estimate the adequacy of the existing shelters. Demand for a shelter was estimated based on the population lived within its coverage area, while the capacity was obtained from secondary data published by the government. Based on the evaluations, a recommendation was made whether any addition of shelter was needed or not.

\section{A. A feature of Padang City}

Padang is the capital city of West Sumatera Province, Indonesia. Astronomically, Padang is located between 0o44' and 01o 08' South Latitude and 100o05' and 100o34' East Longitude [10]. The map of Padang is shown in Fig. 1. From the coast, the terrain of Padang has $3-4 \mathrm{~km}$ of flat land within zero to a five-meter elevation above sea level and then rising toward hills further inland [1]. The population of 
the city in 2014 was 889.646 people [10], which about a half of them were living close to the coast.

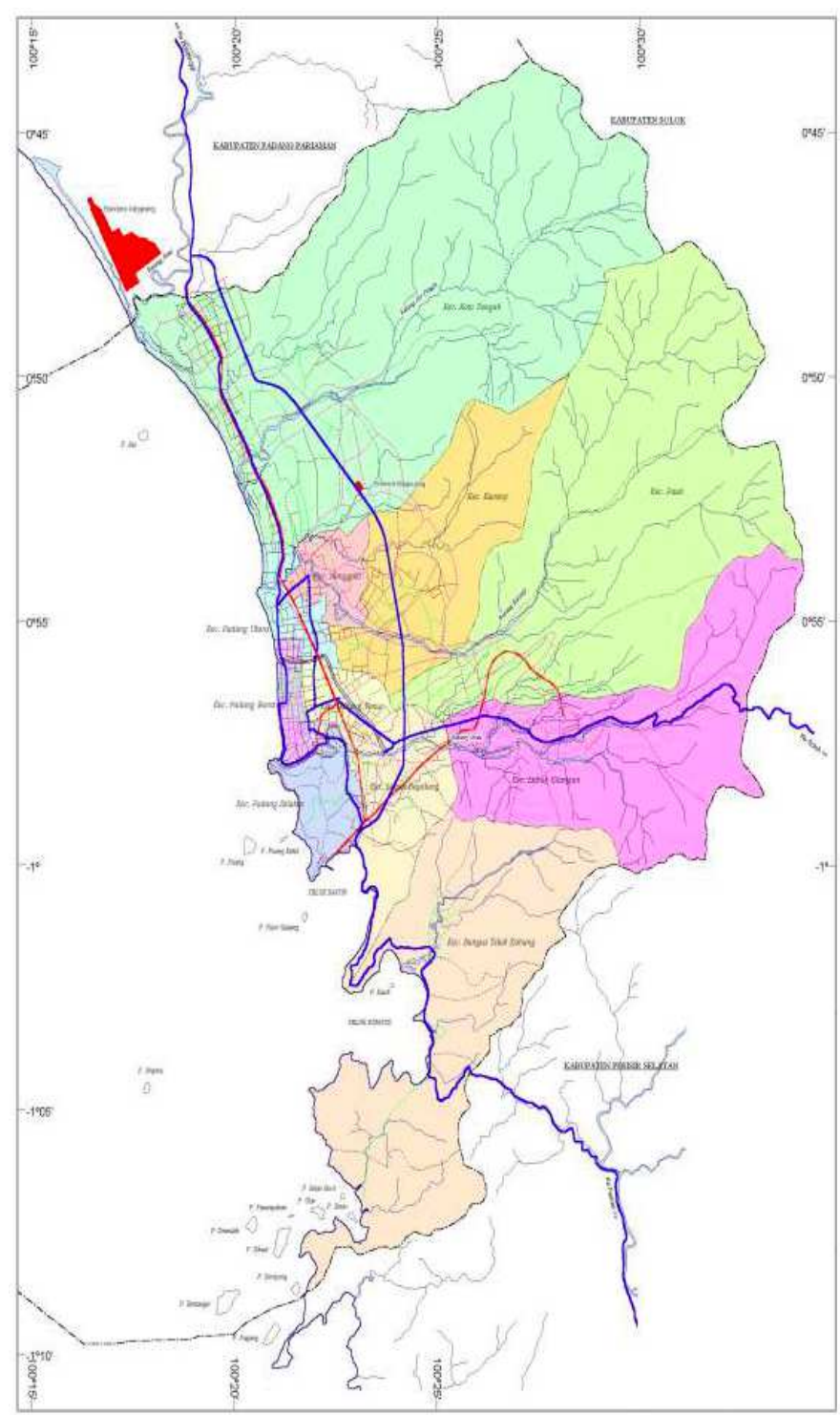

Fig. 1. Map of Padang City [BPS]

Padang was predicted to hit by a massive earthquake with a possibility to trigger tsunami [11]. Many world most massive earthquake have been occurring in the close area of Padang, such as the great M 9.1 earthquake near Aceh on December 26, 2004; M 8.6 near Nias Island in March 28, 2005; M 8.5 and M 7.5 in September 12, 2007 and M 7.8 earthquake on October 25, 2010 which caused a substantial tsunami on the west coast of Mentawai Islands. Although several earthquakes have occurred in the area, a tsunamigenerating earthquake is still a threat [1]. Muhammad et al. [12] predict that Padang may face up to $15 \mathrm{~m}$ tsunami inundation.

\section{B. Shelters' Coverage Area}

An attempt to estimate the coverage area of the existing shelters in Padang has been made with an assumption that the coverage area as a circle with radius $1.37 \mathrm{~km} \mathrm{[3].} \mathrm{The}$ radius was estimated from an experiment, which found that the average walking distance within 17.1 minutes was 1.37 $\mathrm{km}$. The duration of 17.1 minutes was estimated as an effective evacuation time, which was calculated, based on the tsunami wave velocity and distance of the epicenter from the shore. Therefore, the effective evacuation time was estimated from the time required for the wave to reach the shore subtracted by the time required for making evacuation preparation.

However, the assumption was considered less accurate. Kemal et al. [4] attempted to fix the weakness of [3]. Instead of using circles, Kemal et al. [4] argued that the hazard also influence the coverage areas during the evacuation such as river, canyon, buildings, and fenced. Furthermore, Kemal et al. [4] assumed that when the shelter stands between the people and the shore, less possibility for the people to run back approaching the shore to reach the shelter. Therefore, the coverage area would be shaped like a fan. This approach makes more sense; thus the results were used in this study.
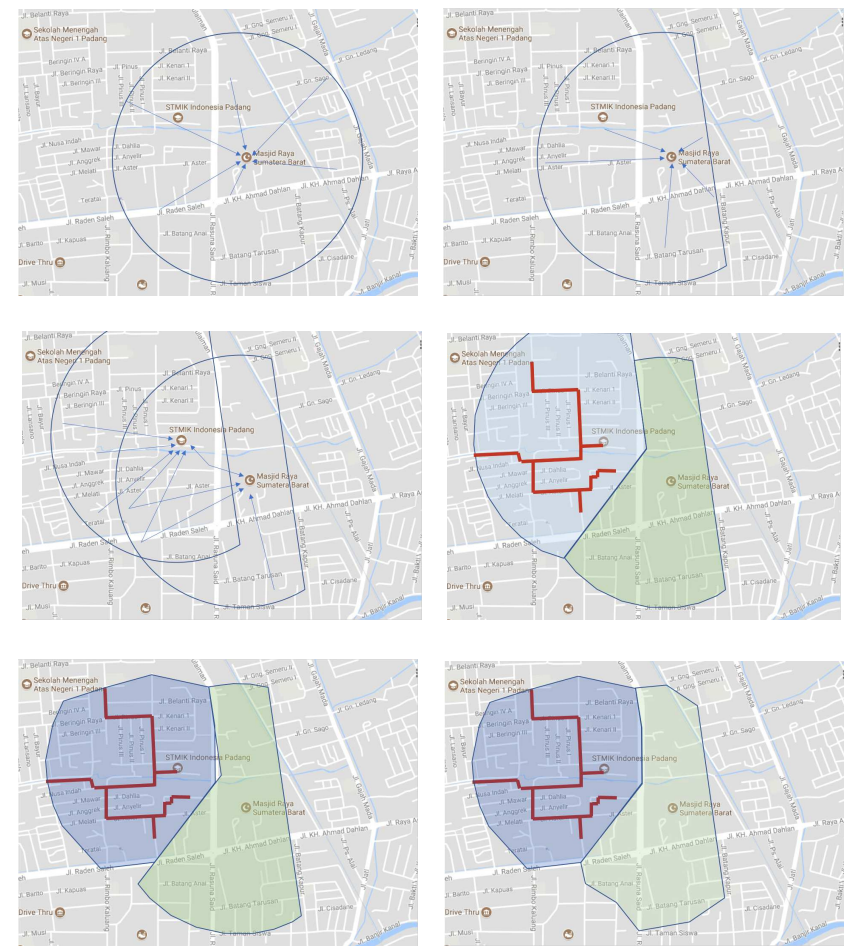

Fig. 2. Steps in drawing the coverage area of shelters (illustrated from [4])

The steps in drawing shelter's coverage area are illustrated in Fig. 2 based on [4]. First, using a shelter as the center, a circle with a radius of $1.37 \mathrm{~km}$ was drawn. Based on the assumption that people tend to evacuate away from the shoreline, except the shelter is close enough to their position, then the circle was cut into two segments through a line parallel to the shoreline. The position of the line is about one-third of the radius from the center, away from the shoreline. Our focus is on the large part. When the coverage areas of two or more shelters coincide, then the boundary will be drawn through the middle point between the shelters. The coverage area was then modified based on the assumption that the evacuation was winding through the existing street for a maximum total distance of $1.37 \mathrm{~km}$ from the shelter.

The demand for each shelter was assumed the density of the population in the coverage area times the area of the shelter coverage. 


\section{Evacuation Plans}

Generally, there are two evacuation plans for tsunami namely horizontal and vertical evacuation plan. The horizontal evacuation plan is the method of evacuation were people in the vulnerable areas are suggested to walk to the nearest hilly ground of $15 \mathrm{~m}$ above sea level or higher than the highest tsunami wave could reach. The vertical evacuation plan is the method of evacuation were people in the vulnerable areas are suggested to walk to the nearest strong with at least 3-storey building or higher than the highest predicted tsunami wave [5].

Perhaps, the horizontal evacuation plan is cheaper and perceived to be more saver than the vertical ones. However, without careful estimation of the walking speed and the distance of the safety zone, horizontal evacuation could be riskier. Therefore, a combination of vertical and horizontal evacuation should be initiated. Those who expected to reach the safe tsunami zones within the effective evacuation time should navigate to the zone and those who could not navigate to the nearest multi-story building (shelter) [5].

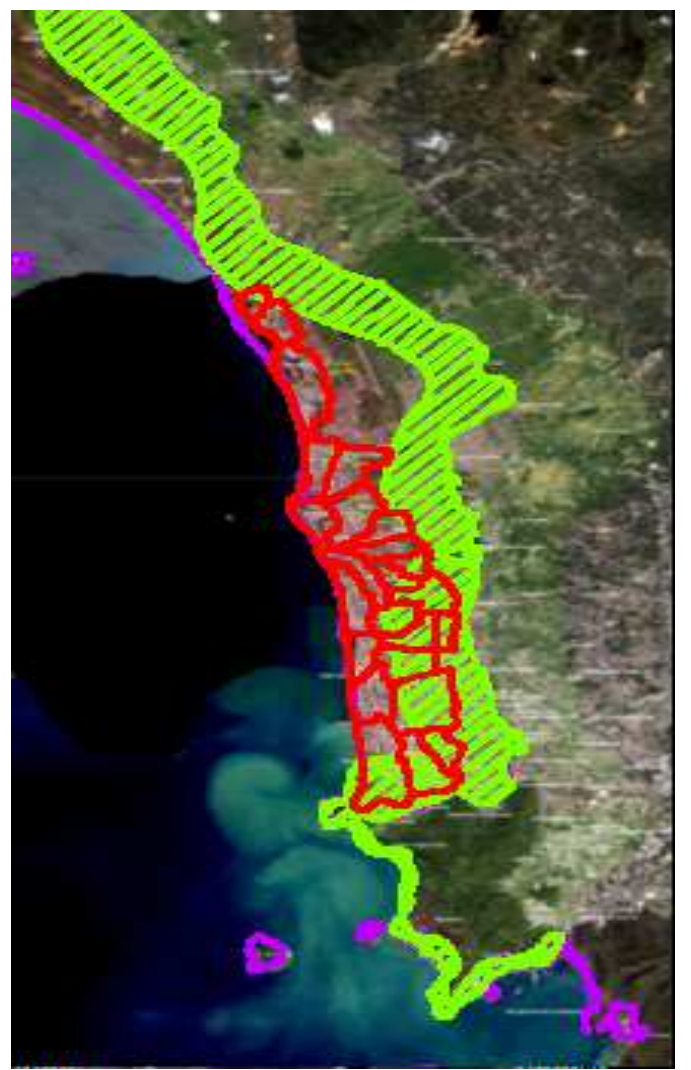

Fig. 3. The coverage area of Combo Evacuation [3]

Yosritzal et al. [3] found that the tsunami arrival time at shoreline was 37.1 minutes, slightly slower than [13], which was 35 minutes. Effective evacuation time was 17.1 minutes, which was estimated to be $1.37 \mathrm{~km}$, walking distance. This walking speed is similar to [14] whose found $1.3 \mathrm{~m} / \mathrm{s}$ for adult and $1.5 \mathrm{~m} / \mathrm{s}$ for children. Using this walking distance, Yosritzal et al. [3] found the suggested area for horizontal evacuation as shown in the green shaded area in Fig. 3. The area covered by a red border is the coverage area of existing shelters where people in the area are suggested to evacuate vertically. Some of the areas are overlapping with the green shaded area suggesting that people in the overlapping areas could choose any of the evacuation plans, horizontally or vertically. It is easy to see that any of the evacuation plans could not cover any part of Padang City. Therefore, either [3] and [4] suggested preparing more shelters to increase the possibility to save the people in the areas. This study will use those findings to estimate the demand for shelters in Padang.

\section{Estimation of Demand}

There were many approaches to estimating the demand for shelter found in literature such as using a geospatial approach based on the satellite image as used in [15]. Building shape, distance, slope elevation, building complexity, etc. are among considered variables. In our opinion, this approach is more realistic for a residential area in the night time. This is because people in a business area are usually not left in the area and people in the residential area would not stay at home in daytime during working hours.

Another possibility is to estimate the demand based on the origin-destination study-using questionnaire. This approach will use questionnaire and ask respondent where they will go if they have to evacuate. However, the respond of the respondents valid only at the time and might not be valid at another time. Moreover, the study budget hungry and more complicated in prediction.

A more promising study was [16], which use an agentbased simulation to identify demand for tsunami shelters, in La Punta, Peru. However, similar to the origin-destination approach, this model is much more complicated and not easy to be implemented in Padang. Furthermore, given that the vulnerable people in Padang might not be the same as the residents of the same area, the model would not accurately predict how and where people to evacuate. Some of the people are living in the safe tsunami region but working or doing business in the vulnerable areas or vice versa.

Wood et al. [17] estimated minimum walking speed of people in the vulnerable area to reach shelter before the tsunami wave reaches the shoreline, instead of estimating the coverage area of the shelter. Wood et al [17] suggested different minimum travel speed to evacuate from hazard zone for each type of walking such as impaired adult ( 0.89 $\mathrm{m} / \mathrm{s})$, slow walk $(1.10 \mathrm{~m} / \mathrm{s} 0$, fast walk $(1.52 \mathrm{~m} / \mathrm{s})$, slow run $(1.79 \mathrm{~m} / \mathrm{s})$ and fast run $(3.85 \mathrm{~m} / \mathrm{s})$ depending on the evacuees' decision to start evacuation, their distance to the safety zone and the minimum available evacuation time. In this context, the decision to start evacuation is playing an important role.

Regarding the start time of evacuation, Sugimoto et al. [18] argue that in general people start evacuation at the different time. Therefore, in their simulation model, Sugimoto et al. [18] divided the population into several groups and assigned a different start time for each group. and Mas et al. [19] threat people individually based on psychological parameters. The delays of resident starting evacuation were caused by psychological factors such as cognitive dissonance and attitudes waiting for a warning. Mas et al. [19] proposed a model based on risk perception.

However, not all of the models could be implemented when the variables could not be estimated. For example, in Sugimoto's model, it is confusing to assigned people in a 
particular location in a particular group, so that the starting time of their evacuation would not be accurately predicted. Psychological parameters are even more difficult to predict as no such data available for the population in Padang. Therefore, we decided to stick with our simplified model and anticipate the worst. We assumed that the evacuation was conducted on foot with the average speed of $1,33 \mathrm{~m} / \mathrm{s}$. When people evacuated on the higher speed, their probability to arrive at the shelter before the wave is higher thus more safety.

\section{E. Demand-Capacity Index (DCI)}

To make a plan, a ratio of demand and capacity of the shelter or Demand-Capacity Index (DCI) was calculated using Eq. (1).

$$
\text { DCI }=\frac{\text { Demand }}{\text { Capacity }}
$$

Demand is the estimated population under the coverage area as discussed in the previous section, while capacity is the estimated capacity of the shelter. Data for the capacity of the shelter was obtained from [2].

\section{MATERIAL AND METHOD}

There are three steps followed in this study such as estimating the demand for each shelter, calculating the ratio demand and capacity (CDI) of the shelters and then estimating demand for additional shelters.

\section{A. Estimating Demand}

As has been discussed in the previous section, demand for each shelter was estimated using geospatial application and base on the population of the area. The fundamental principle in our estimation in this paper is preparing for the worst. Some assumption was made such as evacuation was conducted by walking at $1.33 \mathrm{~m} / \mathrm{s}$ speed that there is no different starting time for the evacuation. It was safer to evacuate immediately after the earthquake, however, some people tent to wait for evacuation orders from the authority [1]. Therefore, the evacuation was assumed to start 20 minutes after the earthquake (see [3] for more detailed).

As an earthquake could happen anytime during day or night-time, there is no specific estimate of the distribution of people in the vulnerable area at the time when the earthquake is happening. People tend to move allots especially during the daytime. However, based on our experience, in the morning people who leave the coastal area to the hills are nearly equal to the people who are moving from the hills to the coastal area during daytime. In this study, we assumed that the population of an administrative village (Kelurahan) is spreading uniformly within the village. The village was used as the smallest cell in this study because of the data is only available for villages and not for any area smaller than villages. Demand for each shelter is estimated as the proportion of the population who are under the coverage area of the shelter and calculated as the ratio of the coverage area of the shelter and the area of the village time's population of the village. Map from Google Earth application and AutoCAD software were used in estimating area size.

\section{B. Estimating the Demand-Capacity Index (DCI)}

After estimating the demand for each shelter, the ratio between demand and capacity was calculated using Eq. (1). The capacity of the shelters is obtained from the Province Office of Regional Disaster Management Agency (BPBD) [2]. The capacity is shown in Table 1.

TABLE I

THE CAPACITY OF SHELTER [2]

\begin{tabular}{|l|l|c|}
\hline ID & \multicolumn{1}{|c|}{ Name } & Capacity \\
\hline 1 & Masjid Raya Sumatera Barat & 4000 \\
\hline 2 & Masjid Nurul Iman & 2500 \\
\hline 3 & Masjid Al Muhajirin & 4000 \\
\hline 4 & Masjid Darussalam & 5000 \\
\hline 5 & Masjid Nurul Haq & 4000 \\
\hline 6 & Hotel Grand Zuri & 3000 \\
\hline 7 & Hotel Ina Muara & 4000 \\
\hline 8 & Hotel Mercure & 3000 \\
\hline 9 & Hotel Ibis & 3000 \\
\hline 10 & BPK Sumbar & 2000 \\
\hline 11 & Kanwil Ditjen Perbendaharaan & 2000 \\
& Negara & 5000 \\
\hline 12 & Kantor Gubernur & 5000 \\
\hline 13 & $\begin{array}{l}\text { Kantor Dinas Prasjaltarkim } \\
\text { Sumbar }\end{array}$ & 2000 \\
\hline 14 & Kantor Bappeda & 2000 \\
\hline 15 & Gedung DPRD & 1000 \\
\hline 16 & Gedung Bank Indonesia & 2000 \\
\hline 17 & Fak. Olah Raga UNP & 2000 \\
\hline 18 & Pascasarjana UBH & 2000 \\
\hline 19 & Gedung Kesenian UNP & 3000 \\
\hline 20 & SMKN 5 & 3000 \\
\hline 21 & TK Al Azhar & 3000 \\
\hline 22 & SMPN 25 & 3000 \\
\hline 23 & SMAN 1 & 3000 \\
\hline 24 & SDN 24 & \\
\hline & & \\
\hline & & \\
\hline
\end{tabular}

\section{Estimating the Additional Shelters}

Based on the DCI, predicted level of service of each shelter is classified into three colours such as red for the overcapacity ones (DCI > 1.0), yellow for the demand nearly equal to the capacity $(0.7<\mathrm{DCI}<1.0)$ and Green for the lesser demand than capacity (DCI $<0.7)$.

The additional shelter is needed near to the existing shelter if the DCI is higher than 1.0. It is recommended to place an additional shelter when the DCI is higher than 0.7 to anticipate the growing demand in the future. Some other shelters are needed in the non-covered area depending on the population in the area.

\section{RESULTS AND DISCUSSION}

Table $2-7$ show the population of each village in 6 districts, which cover several vulnerable villages. The yellow shaded rows are the non-tsunami vulnerable villages because their position is higher than the maximum predicted high of a tsunami wave. LK is the area of the village, LKRT is the vulnerable area within the village, LDTS is the area of the village, which is covered by shelters, $\mathrm{P}$ is population, PRT is the vulnerable population in a village, and JPTS is 
some vulnerable people who are under shelter coverage areas.

The data shows that Koto Tangah and Nanggalo District are the most vulnerable district in Padang because they have many villagers who are not covered by any shelter and could not possibly reach the safety zone during the effective evacuation time.

TABLE II

KOTO TANGAH DISTRICT

\begin{tabular}{|l|c|c|c|c|c|c|}
\hline $\begin{array}{c}\text { Village } \\
\text { Kelurahan })\end{array}$ & $\begin{array}{c}\text { LK } \\
\left(\mathbf{k m}^{\mathbf{2}}\right)\end{array}$ & LKRT & LDTS & $\mathbf{P}$ & PRT & JPTS \\
\hline P Tabing & 9.41 & 9.41 & 2.77 & 20328 & 20328 & 5994 \\
\hline B Pasang & 3.32 & 2.55 & 0.35 & 12333 & 9478 & 1286 \\
\hline PN Tigo & 14.57 & 14.57 & 0.49 & 9427 & 9427 & 319 \\
\hline Gantiang & 3.32 & 2.48 & 0.00 & 13205 & 9848 & 0.00 \\
\hline DT Hitam & 11.78 & 7.33 & 0.00 & 18310 & 11397 & 0.00 \\
\hline A Pacah & 14.72 & 0.12 & 0.00 & 9999 & 80 & 0.00 \\
\hline L Mintrn & 23.29 & 0.00 & 0.00 & 8817 & 0.00 & 0.00 \\
\hline L Buaya & 3.67 & 3.58 & 0.00 & 22438 & 21888 & 0.00 \\
\hline P Sarai & 13.24 & 11.85 & 0.00 & 19390 & 17360 & 0.00 \\
\hline I Koto & 8.18 & 0.00 & 0.00 & 11952 & 0.00 & 0.00 \\
\hline K Pulai & 5.53 & 0.15 & 0.00 & 2424 & 65 & 0.00 \\
\hline B Gadang & 106.90 & 0.00 & 0.00 & 15562 & 0.00 & 0.00 \\
\hline B Panjang & 14.32 & 0.84 & 0.00 & 14226 & 830 & 0.00 \\
\hline
\end{tabular}

TABLE III

PADANG UTARA District

\begin{tabular}{|l|c|c|c|c|c|c|}
\hline $\begin{array}{c}\text { Village } \\
(\text { Kelurahan })\end{array}$ & $\begin{array}{c}\text { LK } \\
\left(\mathbf{k m}^{\mathbf{2}}\right)\end{array}$ & LKRT & LDTS & P & PRT & JPTS \\
\hline ATB & 1.12 & 1.12 & 0.92 & 15901 & 15901 & 13074 \\
\hline ATT & 0.63 & 0.63 & 0.34 & 4239 & 2316 & 1923 \\
\hline UK Utara & 1.53 & 1.53 & 1.53 & 6845 & 6845 & 0.00 \\
\hline UK Selatan & 1.39 & 1.39 & 1.15 & 9023 & 7448 & 0.00 \\
\hline Belanti & 1.62 & 1.62 & 1.62 & 7983 & 7983 & 7983 \\
\hline G Pangilun & 0.42 & 0.25 & 0.07 & 13438 & 7867 & 2123 \\
\hline AP Kopi & 1.37 & 0.28 & 0.01 & 12823 & 2588 & 61 \\
\hline
\end{tabular}

TABLE IV

PADANG BARAT DISTRICT

\begin{tabular}{|l|c|c|c|c|c|c|}
\hline $\begin{array}{c}\text { Village } \\
(\text { Kelurahan })\end{array}$ & $\begin{array}{c}\text { LK } \\
\left(\mathbf{k m}^{2}\right)\end{array}$ & LKRT & LDTS & P & PRT & JPTS \\
\hline Flamboyan & 0.43 & 0.43 & 0.43 & 4795 & 4795 & 4792 \\
\hline R Kaluang & 0.42 & 0.42 & 0.42 & 3914 & 3914 & 3914 \\
\hline P Pasir & 0.71 & 0.71 & 0.71 & 4347 & 4347 & 4347 \\
\hline Purus & 0.68 & 0.68 & 0.68 & 7685 & 7685 & 7685 \\
\hline K Jao & 1.63 & 1.63 & 1.63 & 3939 & 3939 & 3939 \\
\hline K Pondok & 0.65 & 0.65 & 0.65 & 3666 & 3666 & 3666 \\
\hline B Nipah & 0.31 & 0.31 & 0.20 & 5023 & 5023 & 3266 \\
\hline U Gurun & 0.71 & 0.71 & 0.71 & 4912 & 4912 & 4912 \\
\hline Olo & 0.89 & 0.89 & 0.89 & 4777 & 4777 & 4777 \\
\hline B Tangsi & 0.57 & 0.57 & 0.57 & 2788 & 2788 & 0.00 \\
\hline
\end{tabular}

The data of population who are in the coverage area of a shelter is also called as demand and then being compared to the capacity of the shelter and being called DCI. Just in case, people in the coverage area of shelter could reach the safety zone on horizontal evacuation was suggested to conduct horizontal evacuation rather than vertical. Therefore, their data are committed to the analysis of the shelters. Table 8 shows in more detail of each shelter and their DCI indicators.
TABLE V

PADANG TIMUR DisTRICT

\begin{tabular}{|l|c|c|c|c|c|c|}
\hline $\begin{array}{c}\text { Village } \\
(\text { Kelurahan })\end{array}$ & $\begin{array}{c}\text { LK } \\
\left(\mathbf{k m}^{\mathbf{2}}\right)\end{array}$ & LKRT & LDTS & P & PRT & JPTS \\
\hline Sawahan & 8.80 & 6.08 & 1.69 & 5110 & 3529 & 980 \\
\hline GP Gadang & 0.62 & 0.32 & 0.00 & 8913 & 4538 & 24 \\
\hline PG Timur & 0.44 & 0.00 & 0.00 & 8370 & 0.00 & 0.00 \\
\hline K Maraplm & 0.80 & 0.00 & 0.00 & 5753 & 0.00 & 0.00 \\
\hline KDP Krkh & 1.35 & 0.00 & 0.00 & 14084 & 0.00 & 0.00 \\
\hline Andalas & 1.12 & 0.00 & 0.00 & 10390 & 0.00 & 0.00 \\
\hline S Haru & 0.64 & 0.00 & 0.00 & 4571 & 0.00 & 0.00 \\
\hline S Timur & 0.54 & 0.30 & 0.04 & 4982 & 2760 & 394 \\
\hline J Baru & 1.14 & 1.14 & 1.07 & 6479 & 6470 & 6074 \\
\hline Jati & 0.61 & 0.34 & 0.05 & 10323 & 5798 & 868 \\
\hline
\end{tabular}

TABLE VI

PADANG SELATAN DistRICT

\begin{tabular}{|l|c|c|c|c|c|c|}
\hline $\begin{array}{c}\text { Village } \\
(\text { Kelurahan })\end{array}$ & $\begin{array}{c}\text { LK } \\
\left(\mathbf{k m}^{2}\right)\end{array}$ & LKRT & LDTS & P & PRT & JPTS \\
\hline T Bayur & 2.83 & 0.95 & 0.00 & 2995 & 1010 & 0.00 \\
\hline A Manis & 1.19 & 0.14 & 0.00 & 1518 & 174 & 0.00 \\
\hline Rawang & 0.50 & 0.01 & 0.00 & 1064 & 312 & 0.00 \\
\hline M Air & 0.80 & 0.01 & 0.00 & 13537 & 104 & 0.00 \\
\hline B Gado2 & 1.55 & 0.07 & 0.00 & 1426 & 62 & 0.00 \\
\hline B Arau & 0.34 & 0.03 & 0.00 & 4453 & 344 & 0.00 \\
\hline S Palinggm & 0.14 & 0.01 & 0.00 & 3808 & 269 & 0.00 \\
\hline S Padang & 1.54 & 0.89 & 0.00 & 7228 & 4190 & 0.00 \\
\hline P Gadang & 0.31 & 0.31 & 0.07 & 5910 & 5910 & 1288 \\
\hline RP Rumbio & 0.30 & 0.30 & 0.22 & 2811 & 2811 & 2071 \\
\hline B Pondok & 0.25 & 0.25 & 0.25 & 1260 & 1260 & 1260 \\
\hline A Laweh & 0.28 & 0.28 & 0.19 & 3443 & 3443 & 2308 \\
\hline
\end{tabular}

TABLE VII

NANGGALO DISTRICT

\begin{tabular}{|l|c|c|c|c|c|c|}
\hline $\begin{array}{c}\text { Village } \\
\text { (Kelurahan) }\end{array}$ & $\begin{array}{c}\text { LK } \\
\left(\mathbf{k m}^{\mathbf{2}}\right)\end{array}$ & LKRT & LDTS & P & PRT & JPTS \\
\hline TB Gadang & 0.91 & 0.00 & 0.00 & 6339 & 0.00 & 0.00 \\
\hline G Lawas & 0.85 & 0.00 & 0.00 & 3267 & 0.00 & 0.00 \\
\hline K Olo & 0.57 & 0.42 & 0.00 & 7203 & 5319 & 0.00 \\
\hline K Lapai & 0.61 & 0.61 & 0.00 & 10448 & 10448 & 86 \\
\hline S Gadang & 2.28 & 0.24 & 0.00 & 20231 & 2142 & 0.00 \\
\hline K Pagang & 2.85 & 1.11 & 0.00 & 12106 & 4712 & 0.00 \\
\hline
\end{tabular}

TABLE VIII

DCI INDICATOR OF EACH SHELTER

\begin{tabular}{|l|l|c|}
\hline ID & \multicolumn{1}{|c|}{ Shelter Name } & Index \\
\hline 1 & Masjid Raya Sumatera Barat & Green \\
\hline 2 & Masjid Nurul Iman & Yellow \\
\hline 3 & Masjid Al Muhajirin & Green \\
\hline 4 & Masjid Darussalam & Green \\
\hline 5 & Masjid Nurul Haq & Red \\
\hline 6 & Hotel Grand Zuri & Green \\
\hline 7 & Hotel Ina Muara & Yellow \\
\hline 8 & Hotel Mercure & Red \\
\hline 9 & Hotel Ibis & Green \\
\hline 10 & BPK Sumbar & Red \\
\hline 11 & $\begin{array}{l}\text { Kanwil Ditjen Perbendaharaan } \\
\text { Negara }\end{array}$ & Green \\
\hline 12 & Kantor Gubernur & Green \\
\hline 13 & $\begin{array}{l}\text { Kantor Dinas Prasjaltarkim } \\
\text { Sumbar }\end{array}$ & Green \\
\hline 14 & Kantor Bappeda & Green \\
\hline 15 & Gedung DPRD & Red \\
\hline
\end{tabular}




\begin{tabular}{|c|l|c|}
\hline 16 & Gedung Bank Indonesia & Red \\
\hline 17 & Fak. Olah Raga UNP & Red \\
\hline 18 & Pascasarjana UBH & Red \\
\hline 19 & Gedung Kesenian UNP & Red \\
\hline 20 & SMKN 5 & Red \\
\hline 21 & TK Al Azhar & Yellow \\
\hline 22 & SMPN 25 & Green \\
\hline 23 & SMAN 1 & Green \\
\hline 24 & SDN 24 & Red \\
\hline
\end{tabular}

As discussed in the previous section, to make it easy to read, the DCI is indicated by colors. Red is used when DCI $>1.0$ while yellow is used when the DCI is between 0.7 and 1.0 and green when the DCI less than 0.7. The indicator for the DCI is shown in Fig. 4.

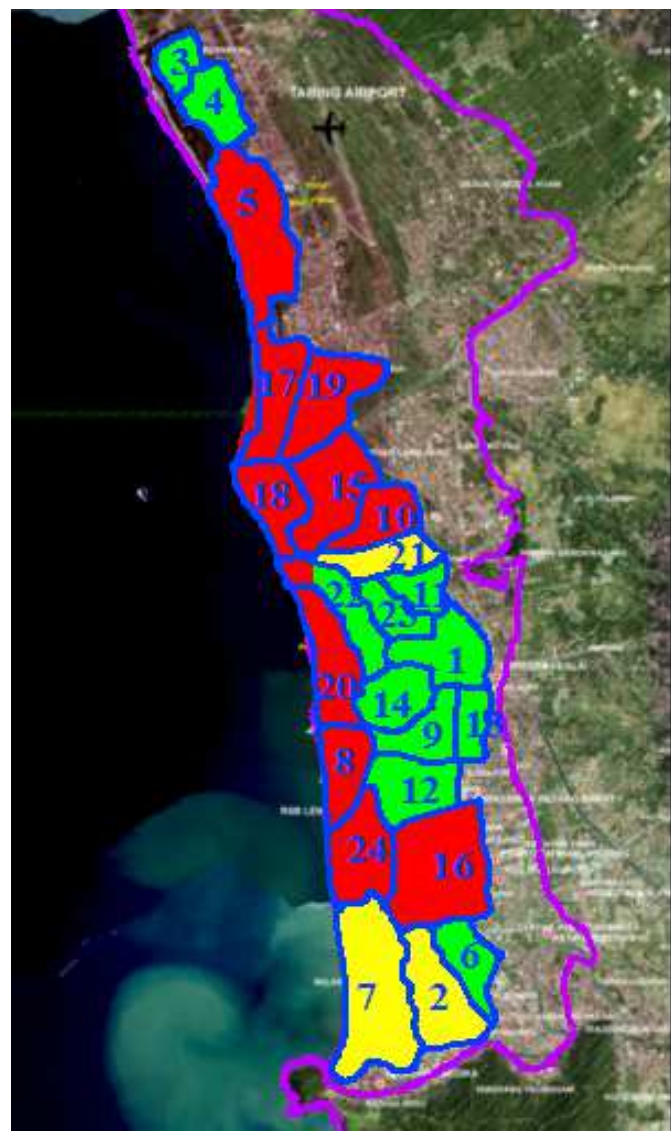

Fig. 4. D/C Indicator of shelters (Red for over capacity, yellow for the equal to capacity and green for the lower than capacity)

There were 13 out of 24 shelters have DCI higher than 0.7 which is mean that those shelters will not adequate to accommodate the demand in the future, as shown in Table 9. The DCI 0.7 has been chosen as the threshold to anticipate overcapacity of the more preferable shelters.

Based on data in Table 9 and location of shelter in the Fig. 3, it can be seen that some red and yellow shelters are located close to each other. Therefore, the additional shelter could be placed in between. For example, between shelter 16 and 24 , some shelters with a total capacity of approximately 2000 are needed. When the additional shelter is prepared to accommodate 1400 evacuees (C 2000 with DCI 0.7), the number of shelters required is shown in Table 10.
TABLE IX

SHELTERS WITH DCI > 0.7 AND EXCESS DEMAND

\begin{tabular}{|c|l|c|c|c|c|}
\hline ID & \multicolumn{1}{|c|}{ Shelter } & DCI & 0.7 C & D & Excess \\
\hline 2 & Masjid Nurul Iman & 0.743 & 1750 & 1858 & 108 \\
\hline 5 & Masjid Nurul Haq & 1.453 & 2800 & 5811 & 3011 \\
\hline 7 & Hotel Inna Muara & 0.974 & 2800 & 3897 & 1097 \\
\hline 8 & Hotel Mercure & 1.514 & 2100 & 4541 & 2441 \\
\hline 10 & BPK Sumbar & 1.515 & 1400 & 3030 & 1630 \\
\hline 15 & DPRD Prov. & 2.959 & 1400 & 5919 & 4519 \\
\hline 16 & Bank Indonesia & 1.375 & 700 & 1375 & 675 \\
\hline 17 & $\begin{array}{l}\text { Fak. Olah Raga } \\
\text { UNP }\end{array}$ & 5.401 & 1400 & 10801 & 9401 \\
\hline 18 & $\begin{array}{l}\text { Pascasarjana } \\
\text { UBH }\end{array}$ & 2.043 & 1400 & 4086 & 2686 \\
\hline 19 & $\begin{array}{l}\text { Gedung Kesenian } \\
\text { UNP }\end{array}$ & 2.196 & 1400 & 4391 & 2991 \\
\hline 20 & SMKN 5 & 1.615 & 2100 & 4846 & 2746 \\
\hline 21 & TK Al Azhar & 0.605 & 2100 & 2409 & 309 \\
\hline 24 & SDN 24 & 2.187 & 2100 & 6561 & 4461 \\
\hline
\end{tabular}

TABLE X

NUMBER OF THE SHELTER WITH A CAPACITY OF 2000 REQUIRED

\begin{tabular}{|c|l|c|c|}
\hline ID & \multicolumn{1}{|c|}{ Shelter } & Excess & C 2000 \\
\hline 5 & Masjid Nurul Haq & 3011 & 2 \\
\hline 2 & Masjid Nurul Iman & 108 & 1 \\
\hline 7 & Hotel Inna Muara & 1097 & \\
\hline 8 & Hotel Mercure & 2441 & 4 \\
\hline 20 & SMKN 5 & 2746 & \\
\hline 10 & BPK Sumbar & 1630 & 5 \\
\hline 15 & DPRD Prov. & 4519 & \\
\hline 21 & TK Al Azhar & 309 & \\
\hline 16 & Bank Indonesia & 675 & 4 \\
\hline 24 & SDN 24 & 4461 & \\
\hline 17 & Fak. Olah Raga UNP & 9401 & 11 \\
\hline 18 & Pascasarjana UBH & 2686 & \\
\hline 19 & Gedung Kesenian UNP & 2991 & \\
\hline & Total & & 27 \\
\hline
\end{tabular}

Looking back to the Fig. 1 and Fig. 2, there are some areas where people in those areas could not possibly reach the safety zone, and no shelters could be reached within the effective evacuation time. Unfortunately, we could not provide a precise estimation of demand in the areas in this paper. It is predicted that to cover those areas, at least ten new shelters with the capacity of 2000 are needed. Therefore, in total, Padang need 37 more shelters with the capacity of 2000 or higher. When the shelter with the minimum capacity of 2000 is not possible, then the number of shelters would be more than 14 .

Please take in mind that those additional shelters are adequate if the government navigate vulnerable people to evacuate to the nearest safety zone, not based on the evacuee preferences. The government should spread many clear and sufficient navigation sign to navigate people to the safety zone. Those who are in the coverage area of a particular shelter are navigated to the shelter except in the case of horizontal evacuation is possible. When the preferences of the evacuee are accommodated, the estimation might not be valid anymore as has been simulated in [19]. Mas et al. [19] found that some shelters are more preferable than others are, therefore in the case of evacuation, the preferred shelters will 
be overloaded while the less preferable shelter will be loaded under capacity.

\section{CONCLUSIONS}

This paper presents the estimation of demand for tsunami shelters in Padang, calculation the ratio of demand and capacity of shelters and estimation of the adequacy of the shelters. The study found that about a half of tsunami shelters in Padang could to overloaded if the vulnerable people to be evacuated to the nearest shelters. Some vulnerable people in some areas could not possibly reach any safety zone either by horizontal neither by vertical evacuation. Those areas are not covered by any shelters and far away from the hilly land. More shelters are needed to increase the possibility to help them from the disaster. In total, this study found that at least 37 more shelters with a capacity of 2000 are needed to ensure entire vulnerable people in Padang getting a help.

\section{ACKNOWLEDGMENT}

We would like to show our gratitude to Faculty of Engineering - the University of Andalas for their financial support under Contract No: 013/UN.16.09.D/PL/2017 and for colleagues at Civil Engineering Department who provide insight and expertise that greatly assisted the research.

\section{REFERENCES}

[1] V. Cedillos, B. G. McAdoo, A. Muhari, and D. H. Natawidjaja. "An Evaluation of Infrastructure for Tsunami Evacuation in Padang, West Sumatera, Indonesia." Proceedings of the $9^{\text {th }}$ U.S. National and $10^{\text {th }}$ Canadian Conference on Earthquake Engineering. Juli 25-29, 2010. Vancouver, Canada.

[2] BPBD Prov. Sumbar. "Shelter di Kota Padang dan Pesisir Selatan." (Shelters in Padang and Pesisir Selatan), Retrieved at $4^{\text {th }}$ September 2016, from url: http://bpbd.sumbarprov.go.id/details/news.

[3] Yosritzal, B. M. Kemal, and F. Siddik. "Estimation of coverage area of tsunami shelters in Padang." Proceeding of National Conference of Applied Sciences, Engineering, Business and Information Technology (ASCNITech). Politeknik Negeri Padang, 15-16 Oktober 2016

[4] Kemal, B.M., Yosritzal, Y.B. Aulia. "Evaluation of Tsunami Evacuation Plans in Padang, Indonesia." IJCIET. In-press.

[5] Stanford. "Conceptual Design of Infrastructure for Evacuation from Tsunami for Padang City, Indonesia,", Stanford University. Final Report. 2009.

[6] E. Mas, A. Suppasri, F. Imamura, and S. Koshimura. "Agent-based simulation of the 2011 great East Japan earthquake tsunami evacuation. An integrated model of tsunami inundation and evacuation." J Nat Disaster Sci 34(1):41-57. 2012.

[7] Tribunnews "Jalur evakuasi tsunami di Padang macet total", (Tsunami evacuation routes in Padang were totally stuck), March 2, 2016 Available http://www.tribunnews.com/regional/2016/03/02/jalur-evakuasitsunami-di-padang-macet-total. Accessed on May 13, 2017.

[8] T. Sato, T. Kono, S. Koshimura, K. Yamaura and F. Imamura. "An Evacuation Model Incorporating Cognitive Dissonance: Introduction of Psychological Elements to Evacuation Simulating." Institute of Social Science 10. 2008.

[9] Sumbaraya. "Walikota paparkan system penanggulangan" (Major explained mitigation system). November 2016. Available at: http://www.sumbaraya.com/2016/11/walikota-paparkan-sistempenanggulangan.html. Accessed on May 13, 2017.

[10] BPS. "Padang dalam Angka 2015." (Padang in Fig.s 2015). Biro Pusat Statistik Kota Padang. 2015.

[11] Rino, Meilano, I., Gumilar, I., and Hilman, D.H (2012) Tectonic Strain in Sumatera Based on Continuous Sumatran GPS Array (SuGAr) Observation 2007-2008. Indonesian Journal of Geospatial Vol. 2, No. 1, 2012.

[12] A. Muhammad, K. Goda, N. A. Alexander, W. Kongko, and A. Muhari. "Tsunami Evacuation Palns for Future Megathrust Earthquakes in Padang, Indonesia Considering Stochastic Earthquake Scenarios. Manuscript under review for journal Natural Hazards Earth System Sciences. Discussion started 4 May 2017.

[13] L. Honesti, M. Z. A. Majid, and M. Muchlian. "Assessing Building Vulnearbility of Tsunami Hazard in Padang. Jurnal Teknologi. July 2014. DOI: $10.11113 /$ jt.v69.3318.

[14] T. Rienne, K. Tillander, and P. Gronberg. "Data collection and analysis of evacuation situations." Espoo 2010. VTT Tiedotteita Research Notes 2562. 46 p. + app. 92 p. 2010.

[15] A. Korman. "Shelter evacuation in relation to demand characteristics in Dominica," Master Thesis. Geographical Information Management and Applications, Untrech University, Delft University of Technology, Wageningen University and Internasional Institute for Geo-Information Science and Earth Observation. 2015.

[16] E. Mas, B. Adriano, S. Koshimura, F. Imamura, J.H. Kuroiwa, F Yamazaki, C. Zavala, and M. Estrada. "Identifying Evacuees" Demand of Tsunami Shelters Using Agent Based Simulation," Book Chapter, Tsunami Events and Lessons Learned Vol 35 of the series Advances in Natural and Technological Hazards Research, 2013. pp 347-358. Springer.

[17] N. Wood, J. Jones, M. Schmidtlein, J. Schelling, and T. Frazier. "Pedestrian Flow-path modelling to Support Tsunami Evacuation and Disaster Relief Planning in the U.S. Pacific Northwest." International Journal of Disaster Risk Reduction. Volume 18 September 2016, pp 41-55.

[18] T. Sugimoto, H. Murakami, Y. Kozuki and K. Nishikawa. "A Human Damage Prediction Method for Tsunami Disasters Incorporating Evacuation Activities." Natural Hazards Vol. 29. 2003. Pp. 585-600.

[19] E. Mas, F. Imamura, S. Koshimura. "Modelling the Decision of Evacuation from Tsunami based on Human Risk Perception." Tohoku Branch Annual Meeting. Sendai: Japan Society of Civil Engineering (JSCE). 2011. 